\title{
Pengaruh Pembelajaran E-learning Berbasis Google Classroom Terhadap Kemampuan Berpikir Kritis Siswa
}

\author{
Jirana $^{* 1}$, Firdaus ${ }^{2}$, Inria $^{3}$ \\ 1,2,3 Universitas Sulawesi Barat \\ email:*1jirana@unsulbar.ac.id, ${ }^{2}$ firdaus@unsulbar.ac.id, ${ }^{3}$ Indria.suardi@gmail.com
}

\begin{abstract}
This study aims to see the effect of google classroom based e-learning on students' critical thinking skills. This research was an experiment research using a quantitative approach, the research design used in this study was a quasi experiment (Nonequivalent control group design). Sample selection used sampling jenuh, the instrument used in this study was a questionnaire of critical thinking skills. Data analysis was performed using descriptive tests and inferential statistical tests. The result of students' critical thinking skills obtained in the descriptive test calculated in the amount of the experimental class was 78.78 , while the control class was 66.63. This shows that the experiment class was 12.15 higher than the control class. This proves that there were differences in students' critical thinking skills in the experiment class and the control class, while the (ttest) significance value of 0.000 was smaller than the significance level of 0.05. Thus it can be concluded that there was an influence on the use of google classroom based e-learning on the critical thinking skills of class XI MIA MAN 1 Majene students'.
\end{abstract}

Keywords: Students' Critical Thinking Skills, E-learning, Google Classroom

\section{PENDAHULUAN}

Keberhasilan dalam pendidikan tidak dapat dipisahkan dari peranan guru sebagai pendidik, dimana guru dalam proses pembelajaran diantaranya sebagai pendidik, pengajar, sumber belajar, fasilitator pembimbing, pengelola dan sebagai inovator. Guru yang profesional dalam proses pembelajaran akan memberikan kesempatan kepada peserta didiknya untuk dapat mengembangkan kemampuan berpikir kritisnya. Kemampuan berpikir kritis adalah kemampuan akal untuk membuat, menganalisis, mengevaluasi serta mengambil keputusan tentang apa yang dia yakini (Hayati, 2020). Berdasarkan survei hasil belajar siswa pada kenyataannya belum sesuai dengan harapan, mutu pendidikan di Indonesia masih rendah yang tercermin dari rendahnya rata-rata hasil belajar siswa yang didasarkan pada hasil studi Program for International Student Assessment (PISA) dan ujian Nasional (UN). Kemampuan siswa di Indonesia menunjukkan masih berada di bawah standar Internasional.

Hasil studi PISA (2018) dalam kategori sains menempatkan Indonesia di peringkat 70 dari 78 negara. Sedangkan dilihat dari data nilai UN siswa SMA/MA Jurusan IPA Biologi tahun pelajaran 2018/2019 dengan nilai rata-rata 49,91 dan nilai rata-rata UN siswa SMA/MA Jurusan IPA mata pelajaran Biologi untuk Provinsi Sulawesi Barat 43,16. Nilai UN siswa Jurusan IPA mata pelajaran Biologi SMA/MA khususnya di Kabupaten Majene dengan nilai rata-rata 44,75. Hasil survei UN tersebut menunjukkan bahwa Kemampuan Siswa Provinsi Sulawesi Barat masih berada pada level kognitif rendah dibandingkan dengan Provinsi-provinsi yang lainnya seperti provinsi Sulawesi tengah, Sulawesi selatan dan DKI Jakarta (Kemendikbud, 2018). Selain hasil PISA dan hasil Ujian Nasional (UN) di Provinsi Sulawesi Barat tahun ajaran 2018/2019 pada Jurusan IPA tingkat SMA/MA. Hasil belajar siswa juga rendah melihat nilai ratarata ulangan harian selama pembelajaran online di masa pandemik covid 19, salah satunya siswa kelas XI MIA di MAN 1 Majene. Selain hasil belajar yang rendah, melalui wawancara kepada guru biologi MAN 1 Majene mengenai kemampuan berpikir kritis siswa juga kurang.

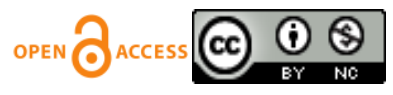


https://jurnal.unsulbar.ac.id/index.php/saintifik

Berdasarkan hasil wawancara peneliti kepada guru biologi MAN 1 Majene tentang pembelajaran online selama masa karantina akibat wabah covid-19, siswa MAN 1 Majene sebelumnya tidak pernah melakukan kegiatan pembelajaran online sehingga siswa perlu beradaptasi terhadap pembelajaran tersebut. Adapun media pembelajaran yang digunakan yaitu media sosial seperti facebook dan whatsapp. Menurut guru biologi MAN 1 Majene dalam wawancaranya bahwa pembelajaran online yang menggunakan media sosial tersebut kurang terjadi interaksi, siswa yang diberikan materi sekedar mencatat tanpa memahami materi dan meninggalkan pertanyaan. Selama pembelajaran biologi berlangsung, banyak siswa yang tidak ikut kelas online. Alasan yang diberikan siswa saat terlambat melakukan pembelajaran online yaitu susah mendapatkan sinyal internet, ketiduran, sedang tidak memiliki kuota internet. Siswa mengatakan bahwa media pembelajaran yang digunakan kurang menarik. Melihat dari perilaku siswa tersebut tidak dapat mengembangkan kemampuan berpikir kritisnya sehingga perlu mencari alternatif media pembelajaran yang bisa mengatasi masalah tersebut agar siswa dapat aktif selama mengikuti pembelajaran.

Alternatif untuk mengatasi permasalahan tersebut adalah dengan menggunakan pembelajaran yang mampu membuat siswa lebih aktif, serta media pembelajaran yang menyediakan fitur-fitur yang menarik agar siswa lebih fokus dalam mengikuti pembelajaran. Pembelajaran e-learning sebagai alternatif media yang sesuai dan memadai untuk menunjang pelaksanaan pembelajaran e-learning. Menurut Basori (2013) pembelajaran e-learning adalah pembelajaran jarak jauh yang memanfaatkan teknologi komputer atau internet. Menurut Ainiyah (2015) bahwa pembelajaran e-learning sebagai penggunaan secara sengaja teknologi informasi dan komunikasi dalam proses belajar dan mengajar. Pembelajaran e-learning dalam pelaksanaannya memerlukan media atau yang lebih dikenal sebagai platform untuk menunjang kegiatan pembelajaran e-learning itu sendiri. Google classroom merupakan sebuah produk aplikasi bagian dari Google Apps for Education (GAFE). Pembelajaran e-learning berbasis google classroom ini merupakan solusi untuk mencapai perubahan-perubahan di masa pandemik covid-19 karena google classroom adalah salah satu platform pembelajaran jarak jauh yang mempunyai banyak keunggulan fitur di dalamnya.

Penelitian sebelumnya telah dilakukan Wahyuaji (2018) bahwa guru membutuhkan e-learning sebagai alternatif solusi untuk melatih kemampuan berpikir kritis dan kreatif siswa. Arifin \& Herman (2018) menyatakan bahwa melalui pembelajaran e-learning siswa dilatih untuk mandiri dalam hal mencari sendiri bahan atau materi pembelajaran, dan lebih bertanggung jawab terhadap proses belajarnya sendiri demi meningkatkan pengetahuannya. Menurut Kustandi (2017) e-learning berbasis google classroom mempunyai pengaruh terhadap peningkatan kemampuan berpikir kritis siswa yang dilihat dari kelebihan $e$ learning berbasis google classroom yakni keaktifan dan berpendapat. Menurut Salamah (2020) melalui google classroom, siswa mampu membaca materi dan mampu menyimpulkan pembelajaran tanpa menggunakan kertas, prestasi siswa juga stabil dan cukup mengalami peningkatan dari tahun-tahun sebelumnya dengan menggunakan media pembelajaran yang berbeda sehingga siswa dapat menerima dan mengikuti pembelajaran yang baik. Berdasarkan latar belakang di atas pembelajaran e-learning berbasis google classroom merupakan pembelajaran yang digunakan untuk menghadapi tantangan di abad 21 dalam mensinergikan teknologi untuk membentuk proses pembelajaran yang lebih baik selama masa pandemik covid-19.

\section{METODE}

Jenis penelitian ini adalah eksperimen. Penelitian eksperimen adalah suatu metode penelitian yang digunakan untuk mencari pengaruh perlakuan tertentu terhadap yang lain (Sugiyono, 2018, p. 34). Desain penelitian yang digunakan dalam penelitian ini yaitu eksperimen semu (Quasi eksperimen). Subjek penelitian ini adalah siswa kelas XI MIA 1 dan MIA 2 MAN 1 Majene. Penelitian dilakukan pada dua kelompok yaitu kelompok eksperimen dan kelompok kontrol yang memiliki kemampuan yang sama dengan pendekatan yang berbeda (Sugiyono, 2018, p. 112). Kelompok eksperimen adalah kelas XI MIA 2 yang akan diberikan perlakuan dengan menggunakan pembelajaran e-learning berbasis google classroom dan kelas kontrol adalah XI MIA 1 yang tidak diberikan perlakuan menggunakan pembelajaran e-learning berbasis google classroom. Waktu penelitian dilaksanakan pada tanggal 2 November Semester Ganjil tahun 
ajaran 2020/2021. Tempat penelitian dilaksanakan secara online atau pembelajaran jarak jauh sesuai dengan tempat tinggal masing-masing siswa Madrasah Aliah Negeri 1 Majene.

Prosedur penelitian dibagi menjadi tiga tahap yaitu tahap awal, tahap pelaksanaan dan tahap akhir. Tahap awal adalah tahap persiapan dari penelitian ini meliputi; (1) Membuat surat izin pra-penelitian untuk melakukan observasi sekolah (2) Melakukan wawancara dengan guru dan siswa (3) Merumuskan masalah yang akan diteliti (4) Menentukan sampel penelitian (5) Memilih materi yang ingin diajarkan dan menyusun perangkat Pembelajaran (RPP) (6) Membuat perangkat instrumen pengumpulan data. Tahap pelaksanaan merupakan tahap pengambilan data, meliputi (1) Pretest dilakukan pada awal pertemuan sebelum memberikan perlakuan pada siswa dengan menggunakan angket skala likert untuk mengetahui kemampuan awal berpikir kritis siswa baik kelompok eksperimen maupun kelompok kontrol (2) Treatment (memberikan perlakuan) pada kelompok eksperimen (XI MIA 2) yaitu diterapkan pembelajaran e-learning berbasis google classroom yang dilakukan dan kelas kontrol (XI MIA 1) yaitu pembelajaran jarak jauh menggunakan whatsapp dengan menyesuaikan pembelajaran yang ada di sekolah MAN 1 Majene (3) Posttest, memberikan angket untuk mengukur kemampuan berpikir kritis siswa dengan tujuan untuk melihat perbandingan kemampuan berpikir kritis siswa yang diberi perlakuan dengan yang tidak diberi perlakuan. Tahap Akhir yaitu tahap analisis dan laporan.

Instrumen yang digunakan dalam penelitian ini yaitu kelengkapan RPP dan angket kemampuan berpikir kritis. Rencana pelaksanaan pembelajaran (RPP) digunakan untuk mengetahui seberapa besar keterlaksanaan model pembelajaran yang digunakan dalam proses pembelajaran dan angket digunakan untuk mengumpulkan data mengenai kemampuan berpikir kritis siswa diperoleh. Angket yang berisikan pernyataan tersebut dibuat berdasarkan indikator kemampuan berpikir kritis (1) Menganalisis argumen, (2) Mampu bertanya, (3) Mampu menjawab pertanyaan, (4) Memecahkan masalah, (5) Membuat kesimpulan (6) Keterampilan mengevaluasi dan menilai hasil dari pengamatan. Pernyataan ini diperoleh sesudah pembelajaran pada kelas eksperimen maupun kelas kontrol. Bentuk angket skala berpikir kritis siswa ini berpedoman pada skala likert yang mempunyai gradasi dari positif dan negatif. Skala likert mempunyai lima kategori jawaban, yaitu sangat setuju (SS), setuju (S), ragu-ragu (RR), tidak setuju (TS) dan sangat tidak setuju (STS). Setiap alternatif jawaban memiliki skor yang berbeda, adalah sebagai berikut:

Tabel 1 Pembobotan skala likert

\begin{tabular}{|l|c|c|c|c|c|}
\hline Pernyataan sikap & SS & S & RR & TS & STS \\
\hline Pernyataan positif & 5 & 4 & 3 & 2 & 1 \\
\hline Pernyataan negatif & 1 & 2 & 3 & 4 & 5 \\
\hline
\end{tabular}

(Sugiyono, 2018, p. 135)

Analisis instrumen yang akan digunakan untuk mengetahui kualitas instrumen dalam penelitian ini menggunakan validitas isi. Validitas digunakan untuk menunjukkan tingkat kevalidan atau kesahihan suatu instrumen. Instrumen RPP dan angket skala berpikir kritis yang disepakati sebelum digunakan akan dinilai oleh 2 orang pakar dan hasil penilaian dari pakar tersebut dianalisis dengan menggunakan validitas isi, secara keseluruhan yang dikemukakan oleh Gregory dalam Retnawati (2016, p. 32), koefisien uji validitas isi instrumen dihitung berdasarkan rumus sebagai berikut:

Validitas isi $=\frac{D}{(A+B+C+D)}$

Keterangan:

A : Ahli 1 memberikan skor lemah, ahli 2 memberikan skor lemah

B : Ahli 1 memberikan skor kuat, ahli 2 memberikan skor lemah

C : Ahli 1 memberikan skor lemah, ahli 2 memberikan skor kuat

D : Ahli 1 memberikan skor kuat, ahli 2 memberikan skor kuat 
https://jurnal.unsulbar.ac.id/index.php/saintifik

Tabel 2 Kontingensi untuk menghitung indeks

\begin{tabular}{|l|l|l|l|}
\hline & & \multicolumn{2}{|c|}{ Ahli 1 } \\
\hline & & Lemah (1/2) & Kuat (3/4) \\
\hline Ahli 2 & Lemah (1/2) & A & B \\
\hline & Kuat (3/4) & C & D \\
\hline
\end{tabular}

(Retnawati, 2016)

Berdasarkan tabel 2 penilaian dua validator ahli dapat diketahui item pertanyaan yang dinyatakan valid dan tidak valid atau yang masih perlu perbaikan. Seperti item status D dapat langsung digunakan, item status B dan $\mathrm{C}$ akan direvisi guna perbaikan sebelum digunakan. Sedangkan untuk item status A akan langsung di buang. Adapun kategori validitas isi dapat dilihat pada tabel berikut:

Tabel 3 Kategori validitas isi

\begin{tabular}{|c|c|}
\hline Kriteria & Kategori \\
\hline $0,8-1$ & Validitas sangat Tinggi \\
\hline $0,6-0,79$ & Validitas Tinggi \\
\hline $0,40-0,59$ & Validitas Sedang \\
\hline $0,20-0,39$ & Validitas Rendah \\
\hline $0,00-0,19$ & Validitas Sangat Rendah \\
\hline
\end{tabular}

(Retnawati dalam Nismawati, 2019)

Teknik analisis data yang digunakan dalam penelitian ini adalah analisis deskriptif dan analisis inferensial dengan menggunakan SPSS version 23. Analisis data secara statistik deskriptif digunakan untuk mendeskripsikan hasil kemampuan berpikir kritis siswa kelas eksperimen dan kelas kontrol setelah mengikuti semua rangkaian pembelajaran. Selanjutnya untuk mendapatkan gambaran yang jelas tentang kemampuan berpikir kritis siswa maka dilakukan penafsiran skala kriteria siswa yang berpikir kritis. Penafsiran tersebut terbagi atas lima kategori yang dapat dilihat pada tabel 4 di bawah:

Tabel 4 Kriteria penafsiran skala kemampuan berpikir kritis siswa

\begin{tabular}{|l|c|c|}
\hline No & Nilai Kemampuan Berpikir Kritis & Kategori \\
\hline 1 & $90-100$ & Sangat Tinggi \\
\hline 2 & $75-89$ & Tinggi \\
\hline 3 & $65-74$ & Sedang \\
\hline 4 & $55-64$ & Rendah \\
\hline 5 & $0-54$ & Sangat Rendah \\
\hline \multicolumn{2}{|r}{ (Masidjo dalam Gupita 2016) }
\end{tabular}

Uji inferensial pada penelitian ini yaitu uji prasyarat dan uji hipotesis. Sebelum dilakukan uji hipotesis, terlebih dahulu harus dilakukan uji normalitas dan uji homogenitas. (1) Uji normalitas, Uji normalitas data pretest dan posttest digunakan untuk mengetahui apakah data pretest dan posttest tersebut berdistribusi normal atau tidak. Uji normalitas menggunakan uji Shapiro Wilk dengan bantuan SPSS 23 untuk a $<5 \%$ dan tingkat kepercayaan 95\%. Kriteria data berdistribusi normal yaitu jika Sig $>0,05$ maka data berdistribusi normal dan Jika Sig < 0,05 maka data tidak berdistribusi normal. (2) Uji homogenitas, dilakukan untuk mengetahui apakah kelompok tersebut memiliki varians yang sama atau homogen untuk 
$\alpha<5 \%$ dan tingkat kepercayaan 95\%. Kriteria data homogen jika Sig $>0,05$ maka data memiliki data varian yang homogen dan jika $\mathrm{Sig}<0,05$ maka data tidak memiliki varian yang homogen.

Pengujian hipotesis pada penelitian ini menggunakan uji Independent sample test). Uji-t digunakan untuk mengetahui serta menguji apakah ada perbedaan kemampuan berpikir kritis siswa kelompok eksperimen (X1 MIA 2) yang diberikan perlakuan penerapan pembelajaran e-learning berbasis google classroom dan kelompok kontrol (XI MIA 1) yang tidak diberikan perlakuan. Statistik yang digunakan adalah uji-t dua pihak untuk membandingkan kelompok eksperimen dengan kelompok kontrol. Uji dengan perbedaan dua rata-rata (uji-t) dengan taraf signifikan $(\alpha=0,05)$ dengan kriteria:

a) Jika sig > 0,05 maka $\mathrm{H} 0$ diterima dan $\mathrm{H} 1$ ditolak

b) Jika sig < 0,05 maka H1 diterima dan H0 ditolak

\section{HASIL DAN PEMBAHASAN}

\subsection{Hasil}

Perhitungan data hasil pretest kemampuan berpikir kritis siswa pada kelas XI MIA 2 sebagai kelompok eksperimen dengan jumlah 18 orang dan kelas XI MIA 1 sebagai kelompok kontrol dengan jumlah 16 orang. Tahap ini belum diberikan perlakuan karena pada tahap ini peneliti hanya ingin mengetahui hasil awal kemampuan berpikir kritis siswa, hasilnya dapat dilihat pada tabel 5 dibawah ini:

Tabel 5 Data skor pretest kelompok eksperimen dan kontrol

\begin{tabular}{|l|c|c|}
\hline \multicolumn{1}{|c|}{ Data } & Eksperimen & Kontrol \\
\hline Nilai Tertinggi & 83 & 88 \\
\hline Nilai Terendah & 49 & 52 \\
\hline Mean & 64 & 66,19 \\
\hline Median & 62,50 & 67 \\
\hline Modus & 49 & 52 \\
\hline Simpangan Baku & 9,69 & 10,02 \\
\hline
\end{tabular}

Berdasarkan tabel 5 di atas, dapat disimpulkan bahwa hasil rata-rata awal kemampuan berpikir kritis siswa kelas eksperimen setelah diberikan pretest adalah 64,00. Pretest bertujuan untuk menggambarkan bagaimana keadaan awal siswa sebelum mendapatkan perlakuan terutama dalam hal kemampuan berpikir kritis siswa sedangkan hasil rata-rata awal kemampuan berpikir kritis siswa kelas kontrol setelah diberikan pretest adalah 66,19. Hasil pretest kelompok eksperimen pada tabel 5 dapat pula disajikan dengan menggunakan tabel distribusi frekuensi dan persentase perolehan nilai hasil kemampuan berpikir kritis siswa pada tabel 6 di bawah ini:

Tabel 6 Distribusi frekuensi dan persentase perolehan nilai hasil pretest kemampuan berpikir kritis siswa kelas eksperimen

\begin{tabular}{|c|c|c|}
\hline \multicolumn{3}{|c|}{ Pretest } \\
\hline Kriteria & Frekuensi (fi) & Persentase (\%) \\
\hline $75-89$ & 3 & 16.7 \\
\hline $65-74$ & 5 & 27.8 \\
\hline $55-64$ & 8 & 44.4 \\
\hline $0-54$ & 2 & 11.1 \\
\hline Jumlah & 18 & 100.0 \\
\hline
\end{tabular}


Berdasarkan tabel 6 di atas, terlihat bahwa nilai awal kemampuan berpikir kritis siswa pada kelas eksperimen yang berada pada kriteria 75-89 (kategori tinggi) terdapat 3 responden (16,7\%), pada kriteria 65- 74 (sedang) terdapat 5 responden $(27,8 \%)$, pada kriteria 55-64 (kategori rendah) terdapat 8 responden $(44,4 \%)$, pada kriteria $0-55$ (kategori sangat rendah) terdapat 2 responden $(11,1 \%)$. Hasil pretest kelompok kontrol pada tabel 6 dapat pula disajikan dengan menggunakan tabel distribusi frekuensi dan persentase perolehan nilai hasil kemampuan berpikir kritis siswa pada tabel 7 di bawah ini:

Tabel 7 Distribusi frekuensi dan persentase perolehan nilai hasil Pretest kemampuan berpikir kritis siswa kelas Kontrol

\begin{tabular}{|c|c|c|}
\hline \multicolumn{3}{|c|}{ Pretest } \\
\hline Kriteria & Frekuensi (fi) & Persentase (\%) \\
\hline $75-89$ & 3 & 18.8 \\
\hline $65-74$ & 7 & 43.8 \\
\hline $55-64$ & 4 & 25.0 \\
\hline $0-54$ & 2 & 12.5 \\
\hline Jumlah & 16 & 100,0 \\
\hline
\end{tabular}

Berdasarkan tabel 7 di atas, terlihat bahwa nilai awal kemampuan berpikir kritis siswa pada kelas kontrol yang berada pada kriteria 75-89 (kategori tinggi) terdapat 3 responden (18,8\%), pada kriteria 65 74 (kategori sedang) terdapat 7 responden (43,8\%), pada kriteria 55-64 (kategori rendah) terdapat 4 responden $(25,0 \%)$, pada kriteria $0-54$ (kategori sangat rendah) terdapat 2 responden $(12,5 \%)$.

\subsection{Data Hasil Posttest Kemampuan Berpikir Kritis Siswa Kelompok Eksperimen dan Kelompok Kontrol}

Data hasil perhitungan posttest kemampuan berpikir kritis pada kelas XI MIA 2 sebagai kelas eksperimen dengan jumlah 18 siswa. Setelah diberikan perlakuan menggunakan pembelajaran e-learning berbasis google classroom hasil olahan data menggunakan SPSS 23 seperti yang tertulis secara rinci pada lampiran 3 dan hasilnya dapat melihat tabel 8 di bawah ini:

Tabel 8 Data skor posttest kelompok eksperimen dan kelompok kontrol

\begin{tabular}{|l|c|c|}
\hline Data & Kelompok Eksperimen & Kelompok Kontrol \\
\hline Nilai Tertinggi & 94 & 87 \\
\hline Nilai Terendah & 67 & 39 \\
\hline Mean & 78,78 & 66,63 \\
\hline Median & 78,50 & 66 \\
\hline Modus & 81 & 64 \\
\hline Simpangan Baku & 6,10 & 10,35 \\
\hline
\end{tabular}

Berdasarkan tabel 8 dapat disimpulkan bahwa nilai rata-rata kemampuan berpikir kritis siswa kelompok eksperimen setelah diberikan posttest adalah 78,78 lebih tinggi dibandingkan dengan nilai ratarata posttest kelompok kontrol. Posttest ini bertujuan untuk menggambarkan bagaimana keadaan siswa setelah mendapatkan perlakuan dengan menggunakan pembelajaran e-learning berbasis google classroom terhadap kemampuan berpikir kritis siswa. Hasil posttest kelompok eksperimen pada tabel 8 dapat pula disajikan dengan menggunakan tabel distribusi frekuensi dan persentase perolehan nilai hasil kemampuan berpikir kritis siswa pada tabel 9 di bawah ini:

Tabel 9 Distribusi frekuensi dan persentase perolehan nilai hasil posttest kemampuan berpikir kritis siswa kelas eksperimen 
https://jurnal.unsulbar.ac.id/index.php/saintifik

\begin{tabular}{|c|c|c|}
\hline & Posttest & \\
\hline Kriteria & Frekuensi (fi) & Persentase (\%) \\
\hline $90-100$ & 1 & 5.6 \\
\hline $75-89$ & 13 & 72.2 \\
\hline $65-74$ & 4 & 22.2 \\
\hline $55-64$ & - & - \\
\hline $0-54$ & - & - \\
\hline Jumlah & 18 & 100,0 \\
\hline
\end{tabular}

Pada tabel di atas terlihat bahwa nilai kemampuan berpikir kritis siswa setelah diberikan angket posttest kemampuan berpikir kritis pada kelas eksperimen yang berada pada kriteria 90-100 (kategori sangat tinggi) terdapat 1 responden $(11,1 \%)$, pada kriteria 75-89 (kategori tinggi) terdapat 13 responden (27,8\%), pada criteria 65-74 (kategori sedang) terdapat 4 responden $(33,3 \%)$. Distribusi frekuensi dan persentase perolehan nilai kemampuan berpikir kritis siswa setelah diberikan perlakuan telah mengalami peningkatan yang sangat baik yaitu berkategori kritis dibandingkan sebelum diberikan perlakuan. Adapun hasil posttest kelompok kontrol kemampuan berpikir kritis siswa pada tabel 9 di atas, dapat pula disajikan dengan menggunakan tabel distribusi frekuensi dan persentase perolehan hasil kemampuan berpikir kritis siswa pada tabel 10 sebagai berikut:

Tabel 10 Distribusi frekuensi dan persentase perolehan nilai hasil posttest kemampuan berpikir kritis siswa kelompok kontrol

\begin{tabular}{|c|c|c|}
\hline \multicolumn{3}{|c|}{ Posttest } \\
\hline Kriteria & Frekuensi (fi) & Persentase (\%) \\
\hline $75-89$ & 3 & 18.8 \\
\hline $65-74$ & 5 & 31.3 \\
\hline $55-64$ & 7 & 43.8 \\
\hline $0-54$ & 1 & 6.3 \\
\hline Jumlah & 16 & 100,0 \\
\hline
\end{tabular}

Berdasarkan tabel 10 di atas, terlihat bahwa nilai posttest kelompok kontrol kemampuan berpikir kritis siswa pada kelas kontrol yang berada pada kriteria 75-89 (kategori tinggi) terdapat 3 responden (18,8\%), pada kriteria 65-74 (kategori sedang) terdapat 5 responden 31,3\%), pada kriteria 55-64 (kategori rendah) terdapat 7 responden (43,8\%), pada kriteria 0-54 (kategori sangat rendah) terdapat 1 responden $(6,3 \%)$. Berdasarkan tabel di atas dapat disimpulkan bahwa kemampuan berpikir kritis siswa setelah diberikan pembelajaran biologi telah mengalami peningkatan yang baik dengan nilai rata-rata kelas eksperimen 78,78 (kategori tinggi) dibandingkan dengan nilai rata-rata kelas kontrol yaitu 66,63 (kategori sedang).

\subsection{Uji Normalitas}

Uji normalitas digunakan untuk mengetahui apakah data yang diperoleh berdistribusi normal atau tidak. Untuk menguji normalitas data, peneliti menggunakan uji Shapiro-wilk dengan bantuan software SPSS version 23. Berikut hasil uji normalitas data kelas eksperimen dan kelas kontrol adalah sebagai berikut:

\section{1) Pretest}

Berikut adalah tabel hasil data yang diperoleh dari perhitungan uji normalitas: 
https://jurnal.unsulbar.ac.id/index.php/saintifik

Tabel 11 Hasil Perhitungan Uji Normalitas

\begin{tabular}{|c|l|c|c|c|c|}
\hline No & \multicolumn{1}{|c|}{ Kelas } & $\begin{array}{c}\text { Jumlah } \\
\text { Sampel }\end{array}$ & Signifikan & $\begin{array}{c}\text { Taraf } \\
\text { Signifikan }\end{array}$ & $\begin{array}{c}\text { Kesimpula } \\
\mathrm{n}\end{array}$ \\
\hline 1 & Eksperimen & 18 & 0,74 & 0,05 & Normal \\
\hline 2 & Kontrol & 16 & 0,62 & 0,05 & Normal \\
\hline
\end{tabular}

Berdasarkan tabel 11 diperoleh nilai signifikan hasil perhitungan uji normalitas pada pretest kemampuan berpikir kritis kelas eksperimen sebesar 0,74 dan pretets kelas kontrol sebesar 0,62 dengan nilai $\alpha$ sebesar 0,05. Diperoleh nilai sig pretest kelas eksperimen sebesar 0,74>0,05 dan nilai sig pretest kelas kontrol sebesar $0,62>0,05$. Terlihat pada nilai sig pretest kelas eksperimen dan nilai sig pretest kelas kontrol lebih besar dari nilai $\alpha$ artinya data berdistribusi normal. Jadi, dapat disimpulkan bahwa kedua data tersebut berdistribusi normal.

2) Posttest

Berikut adalah tabel hasil data yang diperoleh dari perhitungan uji normalitas:

Tabel 12 Hasil Perhitungan Uji Normalitas

\begin{tabular}{|c|l|c|c|c|c|}
\hline No & \multicolumn{1}{|c|}{ Kelas } & $\begin{array}{c}\text { Jumlah } \\
\text { Sampel }\end{array}$ & $\begin{array}{c}\text { Signifika } \\
\mathrm{n}\end{array}$ & $\begin{array}{c}\text { Taraf } \\
\text { Signifikan }\end{array}$ & Kesimpulan \\
\hline 1 & Eksperimen & 18 & 0,71 & 0,05 & Normal \\
\hline 2 & Kontrol & 16 & 0,14 & 0,05 & Normal \\
\hline
\end{tabular}

Berdasarkan tabel 12 diperoleh nilai signifikan hasil perhitungan uji normalitas pada posttest kemampuan berpikir kritis kelas eksperimen sebesar 0,74 dan posttest kelas kontrol sebesar 0,14 dengan nilai $\alpha$ sebesar 0,05. Diperoleh nilai Sig Posttest kelas eksperimen sebesar 0,71>0,05 dan nilai sig posttest kelas kontrol sebesar 0,14>0,05. Terlihat pada nilai sig posttest kelas eksperimen dan nilai sig posttest kelas kontrol lebih besar dari nilai $\alpha$ artinya data berdistribusi normal sehingga dapat disimpulkan bahwa kedua data tersebut berdistribusi normal.

\subsection{Uji Homogenitas}

Uji homogenitas dilakukan untuk mengetahui homogenitas dua sampel yaitu kelas eksperimen dan kelas kontrol. Peneliti menggunakan bantuan SPSS version 23 untuk menguji data homogenitas Hasil uji homogenitas data kelas kontrol dan kelas eksperimen adalah sebagai berikut:

Tabel 13 Hasil Perhitungan Uji Homogenitas

\begin{tabular}{|l|c|c|c|}
\hline $\begin{array}{l}\text { Nilai Kelas } \\
\text { Eksperimen \& } \\
\text { Kontrol }\end{array}$ & Signifikan & $\begin{array}{c}\text { Taraf } \\
\text { Signifikan }\end{array}$ & Kesimpulan \\
\hline Pretest & 0,92 & 0,05 & Homogen \\
\hline Posttest & 0,16 & 0,05 & Homogen \\
\hline
\end{tabular}

Berdasarkan tabel 13 di atas, diperoleh nilai sig pretest sebesar 0,92 dengan nilai $\alpha$ sebesar 0,05 dan nilai Sig Posttest sebesar 0,16 dengan nilai $\alpha$ sebesar 0,05. Jadi, nilai sig $>\alpha$ sebesar 0,05 . Hal ini menunjukkan bahwa nilai sig lebih besar dari nilai $\alpha$ yang artinya kedua data tersebut baik Pretest dan Posttest memiliki varians yang homogen. 
https://jurnal.unsulbar.ac.id/index.php/saintifik

\subsection{Uji Hipotesis}

Pengujian hipotesis dilakukan setelah hasil uji normalitas dan homogenitas yang menunjukkan bahwa data berdistribusi normal dan memiliki varians yang homogen. Pengujian hipotesis ini menggunakan uji Independent Samples Test pada kelas eksperimen dan kelas kontrol dengan bantuan Software SPSS 23 (Perhitungan dapat melihat lampiran 3). Perhatikan tabel berikut ini:

Tabel 14 Hasil Uji Hipotesis

\begin{tabular}{|l|c|c|c|}
\hline \multicolumn{1}{|c|}{$\begin{array}{c}\text { Posttest } \\
\text { Eksperimen \& Kontol }\end{array}$} & Sig. (2-Tailed) & t & Kesimpulan \\
\hline $\begin{array}{l}\text { Kemampuan berpikir kritis } \\
\text { Siswa }\end{array}$ & 0,00 & 4.22 & H0 ditolak dan H1 diterima \\
\hline
\end{tabular}

Berdasarkan tabel 14 di atas, diperoleh hasil sig (2-tailed) posttest kelas eksperimen dan kelas kontrol sebesar 0,00 dengan taraf signifikan sebesar 0,05 dan nilai t sebesar 4,22. Hasil perhitungan menunjukkan bahwa nilai sig<0,05 artinya nilai sig lebih kecil dari taraf signifikan H0 ditolak dan H1 diterima. Sehingga dapat ditarik kesimpulan bahwa terdapat pengaruh model pembelajaran e-learning berbasis google classroom terhadap kemampuan berpikir kritis siswa XI MIA 2 MAN 1 Majene.

\section{PEMBAHASAN}

Hasil analisis deskriptif pada kelas eksperimen dapat diketahui nilai rata-rata posttest berada pada kategori tinggi yang artinya berpikir kritis dan untuk nilai persentase peningkatan kemampuan berpikir kritis per orang pada kelas eksperimen diperoleh jumlah responden pada kategori sedang dan tinggi lebih banyak dibandingkan jumlah responden pada kategori rendah. Hal ini dikarenakan pada kelas eksperimen diberikan perlakuan yaitu menerapkan pembelajaran e-learning berbasis google classroom. Pembelajaran e-learning berbasis google classroom dapat memotivasi siswa lebih aktif dalam pembelajaran sehingga merangsang kemampuan berpikir kritis siswa menjadi lebih baik.

Siswa mengalami perubahan kearah yang lebih baik setelah diterapkannya pembelajaran e-learning berbasis google classroom, awalnya siswa kurang aktif selama proses pembelajaran, setelah diberikan perlakuan siswa menjadi lebih aktif. Selama proses pembelajaran berlangsung, indikator kemampuan berpikir kritis yang sebagai fokus penelitian ini tercapai. Berdasarkan respon yang diberikan siswa melalui angket pernyataan kemampuan berpikir kritis siswa yaitu mampu menganalisis argumen dengan mendiskusikan pendapat yang berbeda dari temannya, mampu menjawab pertanyaan pemecahan masalah yang diberikan, mampu memberikan pertanyaan mengenai materi yang diberikan, mampu membuat kesimpulan dan mampu mengevaluasi seperti memeriksa kembali jawaban ketika diberikan tugas untuk memastikan apakah jawaban tersebut sudah benar dan mencocokkan kembali jawabannya dari sumbersumber yang valid sebelum mengumpulkan tugas di google classroom. Melihat perilaku siswa tersebut, secara tidak sadar siswa mampu mengembangkan kemampuan berpikir kritis mereka sendiri.

Pembelajaran e-learning berbasis google classroom yang digunakan di kelas XI MIA 2 mempunyai kelebihan yang dapat membantu siswa aktif selama melaksanakan pembelajaran di rumah saat masa pandemi covid-19. Siswa mengatakan bahwa selama pembelajaran di rumah pada masa pandemi covid19 lebih baik menggunakan google classroom karena lebih fokus dibandingkan dengan penggunaan media sosial seperti facebook dan whatsapp sebagai media pembelajaran. Penggunaan google classroom lebih fokus membaca materi, mengerjakan soal-soal yang diberikan, mengumpulkan tugas tepat waktu dan menonton video pembelajaran yang langsung tersambung ke youtube, dari pernyataan tersebut, siswa akan membiasakan diri untuk dapat mengevaluasi apa yang siswa lihat, baca dan dengarkan sehingga mampu menganalisis, mampu bertanya, mampu menjawab pertanyaan, mampu memecahkan masalah, mampu membuat kesimpulan. Pernyataan tersebut didukung oleh Royanta et al. (2020) yang menjelaskan bahwa pembelajaran daring melalui google classroom siswa akan memperoleh kebiasaan untuk selalu berpikir, menganalisis segala sesuatu yang mereka baca, lihat dan dengar. Serta dapat memperoleh pembiasaan bagi dirinya untuk selalu berpikir dan memilih mana yang baik dan yang buruk. Wahyuaji (2018),

Pengaruh Pembelajaran E-learning Berbasis Google classroom Terhadap Kemampuan Berpikir Kritis 
https://jurnal.unsulbar.ac.id/index.php/saintifik

menyatakan e-learning sebagai alternatif solusi untuk melatih kemampuan berpikir kritis dan kreatif siswa.

Google classroom merupakan media pembelajaran berbasis internet yang disediakan oleh google sebagai sebuah sistem e-learning. Pembelajaran e-learning berbasis google classroom membantu siswa lebih mandiri dan aktif dalam mencari materi, membaca materi dan menyimpulkan materi tanpa menggunakan kertas. Melalui media pembelajaran e-learning berbasis google classroom siswa memperoleh materi pembelajaran serta tugas yang diberikan berbasis masalah sehingga kemampuan berpikir kritis siswa terlatih. Menurut Solikh, Sulisworo \& Maruto (2018) menjelaskan bahwa dengan pembelajaran e-learning siswa memiliki kesempatan belajar yang lebih fleksibel tanpa terikat ruang dan waktu, memperkaya materi pembelajaran, menghidupkan proses pembelajaran, membuat proses pembelajaran lebih terbuka, meningkatkan efektivitas pembelajaran, serta mendukung peserta didik untuk belajar secara mandiri.

Pembelajaran e-learning berbasis google classroom dapat meningkatkan kemampuan berpikir kritis siswa, pembelajaran e-learning berbasis google classroom dapat diterapkan dalam pembelajaran yang bertujuan untuk meningkatkan pengetahuan, kemampuan, keterampilan serta keaktifan siswa dalam pembelajaran. Sehingga mampu meningkatkan hasil kemampuan berpikir kritis siswa. Dewi et al. (2020), pembelajaran e-learning memberikan keuntungan terhadap pembelajaran itu sendiri. E-learning dapat membawa siswa menuju pembelajaran yang bermakna sehingga siswa aktif dalam pembelajaran. Mampu melatih keterampilan berperilakunya secara nyata, sistematis, serta kritis untuk memecahkan permasalahan.

Menurut Divayana (2017), e-learning memiliki kemampuan serta mempunyai kekuatan dalam menjelajah, memperdalam serta memperluas suatu informasi dimana saja dan kapan saja sehingga terbentuknya budaya semangat dalam belajar. Sedangkan menurut Dwijonagoro \& Suparno (2019) pembelajaran e-learning memberikan keuntungan yang positif pada pengembangan pengetahuan. Beberapa kemampuan yang mampu ditingkatkan berdasarkan indikator-indikator kemampuan berpikir kritis yaitu menuntun siswa dalam mengembangkan kemampuan menuliskan informasi yang sesuai dengan konteks yang dibicarakan dalam masalah, siswa mampu merumuskan masalah/pertanyaan, dilanjutkan dengan menulis penyelesaian masalah. Peningkatan kemampuan berpikir kritis siswa menunjukkan bahwa siswa mampu mengembangkan sesuai dengan indikator yang diharapkan dalam meningkatkan kemampuan berpikir kritis.

Hasil analisis deskriptif kelas kontrol dapat diketahui bahwa nilai rata-rata pretest dan nilai ratarata posttest berada pada kategori sedang yang artinya cukup berpikir kritis. Siswa pada kelas kontrol dalam proses pembelajaran jarak jauh menggunakan whatsapp sebagai aplikasi pembelajaran, siswa tidak diberikan perlakuan pembelajaran e-learning berbasis google classroom sehingga siswa pasif dalam belajar. Whatsapp tidak membantu peserta didik dalam proses pembelajaran karena dengan whatsapp siswa kurang fokus pada pembelajaran yang mengakibatkan hasil nilai rata-rata pretest-posttest kelas kontrol lebih rendah dibandingkan dengan nilai pretest-posttest kelas eksperimen.

Pernyataan paragraf sebelumnya didukung oleh hasil penelitian Susilowati (2020) yaitu selama pembelajaran daring menggunakan group whatsapp tidak banyak responden yang mendapatkan manfaat. Menurut Suarsana (2013), menyebutkan bahwa lingkungan pembelajaran jarak jauh yang memungkinkan siswa mengeksplorasi informasi dari berbagai sumber dengan cepat dan mudah, hal ini mendorong siswa untuk belajar kritis dan selektif dalam memilih informasi yang ada sesuai dengan permasalahan yang diberikan. Tahap ini siswa akan menjawab soal pengayaan untuk mengetahui sejauh mana siswa akan merangsang untuk mengevaluasi setiap pertanyaan yang ada, ketika siswa tersebut tidak dapat mengeksplorasi informasi yang didapat dari berbagai sumber dengan cepat dan mudah, maka siswa tersebut tidak dapat mendorong dirinya untuk belajar mengembangkan kemampuan-kemampuannya, terlebih dalam pengembangan kemampuan berpikir kritis.

Berdasarkan hasil analisis statistik yaitu uji normalitas dan uji homogenitas telah terpenuhi sebagai syarat pengujian hipotesis. Pengujian hipotesis dengan menggunakan uji independent samples test berbantuan SPSS versi 23 diperoleh nilai posttest kelas eksperimen dan kelas kontrol sebesar 0,00 lebih kecil dari taraf signifikan 0,05 yang berarti nilai rata-rata kelas eksperimen lebih tinggi dibandingkan nilai

Pengaruh Pembelajaran E-learning Berbasis Google classroom Terhadap Kemampuan Berpikir Kritis 
https://jurnal.unsulbar.ac.id/index.php/saintifik

rata-rata kelas kontrol setelah diberikan perlakuan. Ini menunjukkan bahwa $\mathrm{H}_{1}$ diterima $\mathrm{H}_{0}$ ditolak yang berarti bahwa penerapan pembelajaran e-learning berbasis google classroom memiliki pengaruh terhadap kemampuan berpikir kritis siswa.

\section{KESIMPULAN}

Hasil penelitian menunjukkan adanya perbedaan kemampuan berpikir kritis siswa antara kelas eksperimen dan kelas kontrol. Nilai rata-rata kemampuan berpikir kritis kelas eksperimen sebesar 78,78 sedangkan kelas kontrol sebesar 66,63. Selisih nilai kemampuan berpikir kritis antara kelas eksperimen dan kelas kontrol sebesar 12,15 . Hasil analisis uji-t yaitu $0,00(\mathrm{sig}<0,05)$ artinya $\mathrm{H}_{1}$ diterima dan $\mathrm{H}_{0}$ ditolak maka peneliti dapat menyimpulkan bahwa terdapat pengaruh pembelajaran e-learning berbasis google classroom terhadap kemampuan berpikir kritis siswa di MAN 1 Majene.

\section{DAFTAR PUSTAKA}

Ainiyah, Z. (2015). Penggunaan edmodo sebagai media pembelajaran e-learning pada mata pelajaran otomatisasi perkantoran di smkn 1 surabaya. Jurnal Administrasi Perkantoran (JPAP). 3(3).

Arifin, F., \& Herman, T. (2018). Pengaruh Pembelajaran E-Learning Model Web Centric Course Terhadap Kemandirian Belajar Matematika Siswa. Jurnal Pendidikan Matematika, 12(2), 1-12.

Basori, B. (2013). Pemanfaatan social learning network" Edmodo" dalam membantu perkuliahan teori bodi otomotif di Prodi PTM JPTK FKIP UNS. Jurnal Ilmiah Pendidikan Teknik Dan Kejuruan, 6(2).

Dewi, K. A. I. D., Suarsana, I. M., \& Juniantari, M. (2020). Pengaruh E-Learning Berbasis Rumah Belajara Terhadap Kemampuan Berpikir Kritis Matematika Siswa.” Wahana Matematika Dan Sains: Jurnal, Sains, Dan Pembelajarannya 14(1), 65-77.

Divayana, D. G. H. (2017). Evaluasi pemanfaatan E-Learning di Universitas Indonesia Menggunakan model CSE-UCLA. Jurna; Cakrawala Pendidikan, 36(2), 280-289.

Dwijonagoro, S., \& Suparno, S. (2019). Pranatacara learning: Modeling mind mapping, e-learning, or hybrid learning? Cakrawala Pendidikan, 38(1), 156-173.

Hayati, U. H. (2020). Pengaruh Metode Focus Group Discussion Terhadap Kemampuan Berpikir Kritis Dan Sikap Sosial Peserta Didik Pada Materi Pencemaran Lingkungan. Doctoral dissertation, UIN Raden Intan Lampung.

Kementrian Pendidikan dan Kebudayaan. (2018). Laporan Hasil Ujian Nasional. Jakarta: Pusat Penilaian Pendidikan.

Kustandi, C. (2017). Efektivitas E-learning Berbasis Edmodo dan Schoology Terhadap Kemmapuan Berfikir Kritis Mahasiswa Program Studi Teknologi Pendidikan FIP UNJ Pada Mata Kuliah Profesi Pendidikan. Educate: Jurnal Teknologi Pendidikan, 2 (1).

PISA (Program For Internasional Student Assesment). (2018). Data Hasil Belajar PISA.

Salamah, W. (2020). Deskripsi Penggunaan Aplikasi Google Classroom dalam Proses Pembelajaran. Jurnal Penelitian dan Pengembangan Pendidikan, 4(3), 533-538.

Suarsana, I. M. (2013). Pengembangan e-modul berorientasi pemecahan masalah untuk meningkatkan keterampilan berpikir kritis. JPI (Jurnal Pendidikan Indonesia), 2 (2).

Solikh, M. N., Sulisworo, D., \& Maruto, G. (2018). Pengaruh model pembelajaran blended learning berbantuan google classroom terhadap kemampuan berpikir kritis ditinjau dari self esteem dan kecerdasan intelektual. Jurnal Materi Dan Pembelajaran Fisika, 8(2), 27-32.

Sugiyono. (2018). Metode Penelitian dan Pendidikan. Bandung: Alfabeta.

Susilowati. E. (2020). Bagaimana Pembelajaran Daring di Tengah Wabah Covid 19 melalui Whatsapp. Jurnal Pendidikan Matematika Reflesia. 5(3), 1-25.

Retnawati, H. (2016). Analisis Kuantitatif Instrumen Penelitian. Purnama Publising. Jl sadew No 1 sorowajan Bartu: Yogyakarta

Pengaruh Pembelajaran E-learning Berbasis Google classroom Terhadap Kemampuan Berpikir Kritis 
Rostyanta, R. I., Sutiadiningsih, A., Bahar, A., \& Miranti, M. (2020). Pengaruh Pembelajaran dengan Google Clasroom diintegrasikan Vidio Interaktif Terhadap Keterampilan Berpikir Kritis Siswa dan Bertanggung Jawab. JTB Vol.9 1 hal.142-1 